\title{
Indian Patent Law and Its Impact on the Pharmaceutical Industry: What Can China Learn from India?
}

\author{
Juan He
}

\begin{abstract}
Both China and India are developing countries in the pharmaceutical industry, and both need to seek a balance between protecting intellectual property rights and satisfying people's healthcare needs. They also need to promote innovation and encourage the development of domestic industries. As members of the WTO, China and India have made a series of amendments to their respective intellectual property systems to live up to the TRIPS Agreement's minimum standards of protection, including recognition of pharmaceutical product patents, introduction of a compulsory licensing system, and Bolar exception. In promoting the development of its domestic pharmaceutical industry, India's experience in legislation and judicial practice deserves serious attention from China, such as using TRIPS's flexibility to facilitate access to medicines, implementing compulsory licensing to create more chances for voluntary licensing negotiation, and updating the guidelines for examining pharmaceutical applications to prevent evergreening of pharmaceutical patents. Meanwhile, learning from India, China should start to provide its legal professionals with knowledge of global rules, to better further Chinese interests in the world arena.
\end{abstract}

\section{Keywords}

Patent $\cdot$ Pharmaceutical industry $\cdot$ Generic drug $\cdot$ Compulsory license $\cdot$ Bolar exception $\cdot$ Evergreening 


\section{$1 \quad$ TRIPS Agreement and India's Pharmaceutical Patent System}

India was an early signatory to the General Agreement on Tariffs and Trade (GATT). ${ }^{1}$ However, it is evident that GATT was more inclined toward developed countries than developing ones. Some developing countries, especially Brazil and India, have proposed during the Uruguay Round negotiations that GATT has no business dealing with the issues of intellectual property protection, which should be discussed at the World Intellectual Property Organization (WIPO); the United Nations Educational, Scientific, and Cultural Organization (UNESCO); and the United Nations Conference on Trade and Development (UNCTAD). During the negotiations, notwithstanding pointing out that countries at different levels of development should have their own right to decide whether to grant patent right to certain products, ${ }^{2}$ India decided to join the nascent World Trade Organization (WTO).

On January 1, 1995, the TRIPS Agreement went into force, which meant that India as a member of the WTO was required to abandon some of its long held position in the intellectual property field to comply with the provisions of the TRIPS Agreement. As a developing country, India obtained a 5-year transition period ${ }^{3}$ and an additional 5 years to amend patent laws on patent protection of pharmaceuticals. ${ }^{4}$ The following analysis is based on the amendments to the Indian Patent Law of 1999, 2002, and 2005 and delineates the impact of the TRIPS Agreement on India's pharmaceutical patent system.

\subsection{Amendment in 1999: Increased Exclusive Marketing Rights in Transition Period}

According to Article 70.8 of the TRIPS Agreement, members that have not provided patent protection for pharmaceuticals and agricultural chemical products as of the date of entry into force of the WTO Agreement are required to provide a means by which applications for patents for such inventions can be filed as of the date of entry into force of the WTO Agreement: to apply the criteria for patentability as laid down in the TRIPS Agreement as if those criteria were being applied on the date of filing in that member country and to provide patent protection from the grant of the patent and for the remainder of the patent term, calculated from the filing date. The purpose of the TRIPS Agreement provision is to maintain the novelty and priority of

\footnotetext{
${ }^{1}$ India acceded to the GATT on July 8, 1948, and became a founding member of the World Trade Organization on January 1, 1995. As a result, India joined the TRIPS Agreement on January 1, 1995. On September 7, 1998, India joined the Paris Convention.

${ }^{2}$ Matthew O'Regan, The Protection of Intellectual Property, International Trade and the European Community: The Impact of the TRIPS Agreement of the Uruguay Round of Multilateral Trade Negotiations, 22 Legal Issues of Economic Integration (1995) Issue 1, 3.

${ }^{3}$ TRIPS Agreement, Article 65.2.

${ }^{4}$ Article 65.4 of the TRIPS Agreement.
} 
such applications. This is also called the "mailbox" application system and is used by developing countries during the transition period.

At the same time, in accordance with the requirements of Article 70.9 of the TRIPS Agreement, although it is not necessary to directly provide patent protection during the transition period, exclusive marketing rights are to be granted to pharmaceuticals and agricultural chemical products provided that, subsequent to the entry into force of the WTO Agreement, a patent application has been filed and a patent granted for that product in another member and marketing approval obtained in such other member. The Patents (Amendment) Act, 1999, was issued on March 26, 1999, but effective since January 1, 1995, which is the effective date of the TRIPS Agreement. The Amendment of 1999 added Chapter IVA after Chapter IV of the Patents Act, 1970, to specifically regulate exclusive marketing rights.

According to the Amendment, ${ }^{5}$ product patent applications can be submitted in the food and pharmaceutical fields, which however will not be subject to patent examination until December 31, 2004. At the same time, the Amendment provides another way to obtain protection, namely, exclusive marketing rights to sell or distribute the article or substance in India. For the application for exclusive right to sell or distribute an article or a substance, the Controller ${ }^{6}$ shall first examine whether the invention is not an invention within the meaning of the Patents $\mathrm{Act}^{7}$ or the invention is an invention for which no patent can be granted. ${ }^{8}$ If the object of the application falls into the abovementioned matters, the application shall be rejected. In a case where an application is not rejected by the Controller, he/she may proceed to grant an exclusive marketing right in the following two situations: (1) the invention claiming the identical article or substance in a convention country has been granted a patent or sale or distribution of the article or substance has been approved. (2) The invention claiming the method or process of manufacture for that invention relating to the identical article or substance has been granted a patent in India. The exclusive marketing right shall be granted by the Controller on behalf of the Central Government. The applicant shall have the exclusive marketing right to himself/herself, his/her agents or licensees to sell or distribute in India the article, or the substance from the date of approval granted by the Controller for a period of 5 years or till the date of grant of patent or the date of rejection of the application for grant of patent, whichever is earlier.

\subsection{Amendment in 2002: Wide-Ranging Changes to Meet the TRIPS Standards}

The Patents (Amendment) Act, 2002, was promulgated on June 25, 2002, and came into force on such dates as the Central Government appointed, by notification in the

\footnotetext{
${ }^{5}$ Chapter IVA Exclusive Marketing Rights of The Patents (Amendment) Act, 1999.

${ }^{6}$ In Indian Patents Act, Controller means the Controller General of Patents, Designs and Trademarks.

${ }^{7}$ Section 3 of the Patents Act, 1970.

${ }^{8}$ Section 4 of the Patents Act, 1970.
} 
Official Gazette, and different dates were designated for different provisions of this Act. ${ }^{9}$ In order to meet the TRIPS standards, many provisions of the Patents Act, 1970, were amended, including the definition of invention, the object of patent protection, the patent term, the requirements of patent application, compulsory licenses, and the Bolar exception, which have a significant impact on India's pharmaceutical patent system.

In relation to the definition of an "invention" under patent law, the TRIPS Agreement clearly stipulates that patents shall be available for any inventions, whether products or processes, in all fields of technology, provided that they are new, involve an inventive step, and are capable of industrial application. ${ }^{10}$ Therefore, the Amendment of 2002 stipulates the definition of invention, that is, a new product or process involving an inventive step and capable of industrial application, and further defines inventive step as a feature that makes the invention not obvious to a person skilled in the art. ${ }^{11}$

On objects that are not capable of protection under patent law, based on the Patents Act, 1970, ${ }^{12}$ the Amendment of 2002 further clarifies that a patent shall not be granted to the following items ${ }^{13}$ : “(1) an invention the primary or intended use or commercial exploitation of which would be contrary to public order of morality or which causes serious prejudice to human, animal or plant life or health or to the environment; (2) discovery of any living thing or non-living substance occurring in nature; (3) any process for diagnostic and therapeutic treatment of human beings or any process for a similar treatment of animals; (4) plants and animals in whole or any part thereof other than micro-organisms but including seeds, varieties and species and essentially biological processes for production or propagation of plants and animals; (5) a mathematical or business method or a computer program per se or algorithms; (7) a literary, dramatic, musical or artistic work or any other aesthetic creation whatsoever including cinematographic works and television productions; (8) a mere scheme or rule or method of performing mental act or method of playing game; (9) a presentation of information; (10) topography of integrated circuits; (11) an invention which, in effect, is traditional knowledge or which is an aggregation or duplication of known properties of traditionally known component or components."

On the term of patent protection, according to the TRIPS Agreement, ${ }^{14}$ the term of protection available shall not end before the expiration of a period of 20 years counted from the filing date. However, Section 53 of the Patents Act, 1970, stipulates that the term of a patent in respect of an invention claiming the method or process of manufacture of a substance, where the substance is intended for use, or is capable of being used, as food or as a medicine or drug, shall be 5 years from the

\footnotetext{
${ }^{9}$ Section 1 of the Patents (Amendment) Act, 2002.

${ }^{10}$ Article 27.1 of the TRIPS Agreement.

${ }^{11}$ Section 3(f) of the Patents (Amendment) Act, 2002.

${ }^{12}$ Section 3. Chapter II Inventions not Patentable of the Patents Act, 1970.

${ }^{13}$ Section 4 of the Patents (Amendment) Act, 2002.

${ }^{14}$ Article 33 of the TRIPS Agreement.
} 
date of sealing of the patent or 7 years from the date of the patent, whichever period is shorter, and, in respect of any other invention, shall be 14 years from the date of the patent. The Amendment of 2002 extended the term of protection of all patents to 20 years in accordance with the TRIPS requirement. ${ }^{15}$ The Amendment stipulates that the term of every patent granted, after the commencement of the Patents (Amendment) Act, 2002, and the term of every patent which has not expired and has not ceased to have effect, on the date of such commencement, shall be 20 years from the date of filing of the application for the patent.

On the subject of compulsory license, the Amendment has made a number of changes in accordance with the TRIPS Agreement and the Doha Declaration. First of all, the Amendment further clarified the grounds for compulsory license on the basis of the Patents Act, $1970,{ }^{16}$ that is, at any time after the expiration of 3 years from the date of the sealing of a patent, any person interested may make an application to the Controller for grant of a compulsory license for a patent on any of the following grounds: (1) that the reasonable requirements of the public with respect to the patented invention have not been satisfied; (2) that the patented invention is not available to the public at a reasonably affordable price; and (3) that the patented invention is not worked in the territory of India. The third ground was introduced via the Amendment. ${ }^{17}$

In addition, the Amendment also provides a special provision for compulsory licenses on notification by the Central Government, ${ }^{18}$ which may be issued in a circumstance of national emergency, extreme emergency, or a case of public noncommercial use, including public health crises, relating to AIDS, human immunodeficiency virus, tuberculosis, malaria, or other epidemics. At the same time, the amendment also provides for the termination of a compulsory license by the Controller, ${ }^{19}$ namely, if and when the circumstances that gave rise to the grant thereof no longer exist and such circumstances are unlikely to recur.

On exceptions for patent infringement, the TRIPS Agreement stipulates that members may provide limited exceptions to the exclusive rights conferred by a patent, provided that such exceptions do not unreasonably conflict with the normal exploitation of the patent and do not unreasonably prejudice the legitimate interests of the patent owner, taking account of the legitimate interests of third parties. ${ }^{20}$ Based on the Patents Act, $1970,{ }^{21}$ the Amendment inserted a provision for certain acts not to be considered infringement, also known as regulatory exceptions. That is, any act of making, constructing, using, or selling a patented invention solely for uses reasonably relating to the development and submission of information required under any law for the time being in force, in India, or in a country other than India, which

\footnotetext{
${ }^{15}$ Section 27(a) of the Patents (Amendment) Act, 2002.

${ }^{16}$ Section 84 of the Patents Act, 1970.

${ }^{17}$ Sections 39 and 84 of the Patents (Amendment) Act, 2002.

${ }^{18}$ Sections 39 and 92 of the Patents (Amendment) Act, 2002.

${ }^{19}$ Sections 39 and 94 of the Patents (Amendment) Act, 2002.

${ }^{20}$ Article 30 of the TRIPS Agreement.

${ }^{21}$ Section 107 of the Patents Act, 1970.
} 
regulates the manufacture, construction, use, or sale of any product, shall not be considered an infringement of patent rights. ${ }^{22}$ According to this provision, generic pharmaceutical manufacturers are allowed to use the patented invention to obtain market approval from a regulatory agency for medicines and healthcare products, without the patent holders' permission. This rule is also known as the Bolar exception.

\subsection{Amendment in 2005: Comprehensive Improvement Before the Expiration of Transition Period}

The Patents (Amendment) Act, 2005, was promulgated on April 4, 2005. While some specific provisions came into force on dates set by the Central Government, the remaining provisions came into force on January 1, 2005, when India's transition period expired. The Amendment of 2005 is crucial for India to fully implement the TRIPS obligations.

The most important change introduced by the Amendment is the omission of Section 5 of the Patents Act, $1970,{ }^{23}$ which provided that no patent shall be granted in respect of claims for substances intended for use, or capable of being used, as food or as medicine or drug or relating to substances prepared or produced by chemical processes. ${ }^{24}$ The Amendment also omitted Chapter IVA "Exclusive Marketing Rights," which was inserted into the Act by the Amendment of 1999. ${ }^{25}$ This means that, after the expiration of the transition period, in accordance with the TRIPS requirement, ${ }^{26}$ patents shall be available for any inventions, whether products or processes, in all fields of technology.

The Amendment also made important adjustments to provisions on compulsory licenses. First, the Amendment added compulsory license for export of patented pharmaceutical products in certain exceptional circumstances. ${ }^{27}$ The TRIPS Agreement stipulates that a compulsory license may only be issued predominantly for the supply of the domestic market of the member granting the license. ${ }^{28}$ However, many countries without a significant pharmaceutical sector have not been able to take advantage of the compulsory licensing provisions of the TRIPS Agreement. Paragraph 6 of the Doha Declaration is aimed at finding a solution to the problem. ${ }^{29}$ Therefore, the Amendment inserted a new section, ${ }^{30}$ which states that a compulsory license shall be available for manufacture and export of patented pharmaceutical

\footnotetext{
${ }^{22}$ Section 44 of the Patents (Amendment) Act, 2002.

${ }^{23}$ Section 5 of the Patents Act, 1970.

${ }^{24}$ Section 4 of the Patents (Amendment) Act, 2005.

${ }^{25}$ Section 21 of the Patents (Amendment) Act, 2005.

${ }^{26}$ Article 27.1 of the TRIPS Agreement.

${ }^{27}$ Section 55 of the Patents (Amendment) Act, 2005.

${ }^{28}$ Article 31(f) of the TRIPS Agreement.

${ }^{29}$ WTO General Council, The Implementation of Paragraph 6 of the Doha Declaration the TRIPS Agreement and Public Health, WT/L/540, August 30, 2003.

${ }^{30}$ Section 55 of the Patents (Amendment) Act, 2005.
} 
products to any country having insufficient or no manufacturing capacity in the pharmaceutical sector for the concerned product to address public health problems, provided that a compulsory license that has been granted by such country or such country has allowed importation of the patented pharmaceutical products from India. Pharmaceutical product here means any patented product or product manufactured through a patented process of the pharmaceutical sector.

Secondly, the Amendment added a special situation of compulsory license. According to the mailbox application system stipulated in the Amendment of 1999, applications in respect of a claim for the substances in the pharmaceutical sector could be filed, but these applications were not examined until January 1, 2005. The Amendment of 2005 inserted a new section, stating that, for product inventions in the pharmaceutical and chemical sector, the patent holder shall only be entitled to receive reasonable royalty from such enterprises which have made significant investment and were producing and marketing the concerned product prior to January 1,2005 , and which continue to manufacture the product covered by the patent on the date of granting of the patent, and no infringement proceedings shall be instituted against such enterprises. ${ }^{31}$ This means that a product patent entering the mailbox application system is in essence facing the same treatment as a compulsory license, to a certain degree.

Another important change brought by the Amendment is the addition of a situation that is not considered to be an infringement of patent rights. The Amendment of 2002 added the Bolar exception for the first time, ${ }^{32}$ while the Amendment of 2005 extended the scope of application of the Bolar exception to importation. ${ }^{33}$ This means that any act of marking, constructing, using, selling, or importing a patented invention solely for uses reasonably related to the development and submission of information required under any law in India or in other country, which act regulates the manufacture, construction, use, sale, or import of any product, shall not be considered an infringement of patent rights. This provision mainly focuses on pharmaceutical products and medical instruments.

\section{The Impact of Indian Patent Law on the Local Pharmaceutical Industry}

\subsection{Rejection of Product Patent}

The Report on the Revision of the Patent Law submitted by the Patent Law Amendment Commission in 1959, ${ }^{34}$ which was led by Shri Justice N. Rajagopala Ayyangar, pointed out that at that time foreigners held $80 \%$ to $90 \%$ of India's

\footnotetext{
${ }^{31}$ Section 10(c) of the Patents (Amendment) Act, 2005.

${ }^{32}$ Section 44 of the Patents (Amendment) Act, 2002.

${ }^{33}$ Section 58(a) of the Patents (Amendment) Act, 2005.

${ }^{34}$ Shri Justice N. Rajagopala Ayyangar, Report on the Revision of the Patent Law, Government of India, September 1959, 274, 285.
} 
patents, of which $90 \%$ of the patented products were not manufactured in the Indian territory. Foreign companies could block the production of their patented drugs in India, causing the stagnation of the Indian domestic pharmaceutical industry. Thus, the Commission believed that the patent system had been used by multinational corporations to monopolize the market, especially in the food, pharmaceutical, and chemical industries. Market monopolies also led to high product prices. Therefore, the Commission recommended that only methods or processes in the abovementioned fields be patentable, as opposed to the Indian Patents and Designs Act of 1911, which granted patent to both product and process inventions in the pharmaceutical sector.

This suggestion was adopted by the Patents Act of 1970, which has laid the foundation for the boom in India's generic drug industry. According to the Patents Act of 1970, no patent shall be granted in respect of claims for substances intended for use or capable of being used as medicine or drug or relating to substances prepared or produced by chemical processes. The reason that the Patents Act of 1970 only grants method patents in the fields of pharmaceuticals and chemicals is because product patents have an inhibitory effect on other related research, as they can prevent others from obtaining the same products through different methods. Once product patents are granted to drugs, patentees can control the production of patented drugs and thereby unreasonably raise the prices of essential medicines. ${ }^{35}$ Thus, the rejection of the drug product patents guaranteed that India's generic companies could produce drugs with the same or similar composition through reverse engineering and avoid being accused of infringement. India denied product patents in the pharmaceutical sector until the expiration of the transition period of the TRIPS Agreement on January 1,2005 . The rejection of product patents in the pharmaceutical sector for more than 30 years has created an opportunity for the development of the generic drug industry in India.

After comparing drug prices among India, the United Kingdom, Malaysia, and Nigeria, before and after the Indian Patents Act of 1970, R.B. Saxena, consultant at the Indian Council for Research on International Economic Relations, found ${ }^{36}$ that the prices of pharmaceutical products in India were highest before the enactment of the Patents Act of 1970 and that in 1987 the prices in India for commonly used drugs, such as analgin tablets, doxycycline capsules, diazepam tablets, and metronidazole tablets, were low compared to those of other countries. The research also found that some of the important new drugs could be introduced into India with a time lag ranging between only 4 and 6 years. Thus, Saxena pointed out that the changes relating to process patenting incorporated in the Indian Patents Act of 1970 had benefited Indian consumers in terms of prices paid for drugs and medicines and, meanwhile, it also became possible to produce many new pharmaceutical products in India much faster than what could have been otherwise.

\footnotetext{
${ }^{35}$ R.B. Saxena, Trade-Related Issues of Intellectual Property Rights and the Indian Patent Act: A Negotiating Strategy, 12 World Competition (1988), Issue 2, 92.

${ }^{36}$ Ibid.
} 


\subsection{Mailbox Application Mechanism}

The mailbox application mechanism during the transition period allowed India not only to meet the TRIPS requirements but also to take into account India's own development needs. India's transition period for complying with the TRIPS obligations related to pharmaceuticals was 1995 to 2005 . According to the Amendment of 1999, applications in respect of a claim for the substances in the pharmaceutical sector could be filed and entered into the mailbox system but were not processed until January 1, 2005; and the application could be granted exclusive marketing rights to sell or distribute the article or substance in India.

Before 2005, local pharmaceutical companies were allowed to reverse-engineer the best-selling drugs and produce cheap generic drugs for the domestic market and export them to Russia, China, Brazil, and Africa. In the process of producing generic drugs, Indian pharmaceutical companies accumulated extensive experience and trained their own technical personnel. During the transition period, Indian domestic pharmaceutical companies allied with each other to conduct R\&D and to manufacture pharmaceuticals for multinational pharmaceutical companies. The Indian domestic pharmaceutical industry grew rapidly, and some local pharmaceutical companies embarked on medicinal R\&D and applied for drug patents in the United States and the European Union. ${ }^{37}$

The transition decade was the fastest growing period for the Indian pharmaceutical companies, and the industry became one of the most lucrative sectors in India. Research ${ }^{38}$ shows that the average profit margin (profit as a percentage of sales) of the pharmaceutical industry was about $8.8 \%$ in 1995 (while the profit margin of the chemical industry was $5.8 \%$, that of the food and beverage industry was $4.8 \%$, and that of the machinery manufacturing industry was $5.5 \%$ ) and shot up to $15.4 \%$ in 2005 . At the same time, generic drugs entering the Indian market grew rapidly. From 1980 to 1990, only 10 generic drugs entered the Indian market; the number reached 99 during the period 1990-1995, 156 during the period 1995-2000, and 262 during the period 2000-2005. It can be inferred that the transition period was a golden decade for the development of the Indian pharmaceutical industry.

After 2005, India started to examine product patent applications, which led Indian pharmaceutical companies to adjust their product development policy and to increase R\&D investment. At the same time, multinational pharmaceutical and biotech corporations started to increase contracted R\&D and manufacturing in the Indian market.

\footnotetext{
${ }^{37}$ Ravi Sarathy, Strategic Evolution and Partnering in the India Pharmaceutical Industry, in Subhash C. Jain (ed.), Emerging Economies and the Transformation of International Business: Brazil, Russia, India and China (BRICs), Edward Elgar Publishing Ltd., 2016, 229.

${ }^{38}$ Mainak Mazumdar, Performance of Pharmaceutical Companies in India, Springer, 2013, 32.
} 


\subsection{Compulsory Licensing System}

In the Patents Act of 1970, there was already a special chapter for compulsory licenses, and the system was further improved in the Patents (Amendment) Act of 2002 and 2005. The compulsory licensing system creates more chance for voluntary licensing negotiation between the domestic Indian pharmaceutical companies and multinational corporations to succeed.

According to Indian Patent Law, after the expiration of 3 years from the date of the sealing of a patent, any person interested may make an application to the Controller. The applicant is required to first attempt to procure a voluntary license from the patentee before applying for a compulsory license. If this attempt does not come to fruition within 6 months of the initial request, the applicant is entitled to file a compulsory license application.

In 2012, the Controller, upon the application of Natco Pharma Ltd. (Natco), granted a compulsory license on Nexavar (Sorafenib Tosylate), a kidney cancer medicine patented by Bayer Corporation (Bayer). ${ }^{39}$ This is the first ever and only compulsory license in India. One of the grounds on which the Controller made the decision was that the drug Nexavar was not manufactured in India but was instead imported and marketed in the Indian market and the term of "(not) work(ed)" only means manufacturing and does not include importing or selling.

The Controller pointed out that the grounds for issuing compulsory licenses are not defined in the TRIPS Agreement itself, which leaves considerable discretion to WTO members as to how to apply the criteria within their national laws. The Controller also emphasized that the use of these flexibilities can directly or indirectly help the low- and middle-income countries to achieve a balance between intellectual property protection and specific developmental priorities, including the attainment of national public health objectives. ${ }^{40}$ The decision of the Controller was subsequently reviewed by the Intellectual Property Appellate Board (IPAB) and courts and was finally confirmed by the Supreme Court in 2014, despite fears that the compulsory license might discourage foreign direct investment in India. ${ }^{41}$

Admittedly, the Nexavar case in the long run will make patentees aware of the possibility of compulsory licensing and be more ready to enter into voluntary licensing, thus creating more space for voluntary licensing negotiations, which would in turn help lower drug prices.

Thereafter, the Controller has been very cautious in issuing compulsory licenses. For example, in March 2013 BDR Pharmaceuticals Intl. Pvt. Ltd. (BDR) requested a compulsory license on Bristol-Myers Squibb's cancer drug Dasatinib,

\footnotetext{
${ }^{39} \mathrm{Ibid}$.

${ }^{40}$ Decision of the Controller in Compulsory License Application No. 1 of 2011, March 9, 2012; Application for Compulsory Licence under Section 84(1) of the Patents Act, 1970, in respect of Patent No. 215758, 41. Available at http://patentdocs.typepad.com/files/compulsory-license-application.pdf

${ }^{41}$ James J. Nedumpara and Prateek Misra, Natco v. Bayer: Indian Patent Authority Grants Its First Ever Compulsory License on Pharmaceutical Products, 7 Global Trade and Customs (2012), 328.
} 
which is used by patients with chronic myeloid leukemia. BDR also submitted that the price of each tablet sold by the patentee was INR 2761, working out to INR 1, 65,680 for 60 tablets per month per patient. ${ }^{42}$ BDR promised that after obtaining the license, it would make the drug available to the public at a price of INR 135 per tablet, which would amount to INR 8100 per month, and moreover, it would provide the drug for free to a certain percentage of patients. However, the Controller rejected BDR's application in October 2013, on the ground that BRD has not made enough efforts to obtain a voluntary license for the drug. Through this rejection, the Controller has shown that any decision on compulsory license will be carefully made and patent right will be duly protected. ${ }^{43}$ This approach effectively balances the interests of multinational corporate patentees and domestic generic companies.

\subsection{Interpretation of Patentable Subject Matter}

The flexibility to interpret patentable subject matter creates opportunities for the domestic generic drug companies to challenge a pharmaceutical patent in India. Given that the term "invention" is not defined in the TRIPS Agreement, there is flexibility to interpret patentable subject matter. The Indian Patents (Amendment) Act of 2005 excludes any new form of a known substance from patentable subject matter, if the new form does not result in enhancement in efficacy. This amendment would make it easier to challenge a pharmaceutical patent in India.

In the Novartis v. Union of India case, the patent application on Gleevec was rejected by the Controller, which rejection was upheld by the IPAB and eventually by the Supreme Court on the ground that the patent failed to meet the requirements of section 3(d) of the Patents (Amendment) Act of 2005. According to section 3(d), a modification of a known drug is only patentable when it enhances therapeutic efficacy. The Supreme Court decided that the substance that Novartis sought to patent was indeed a modification of a known drug imatinib, which was disclosed in the 1993 patent application. However, Novartis did not present evidence of a difference in therapeutic efficacy between the final form of Gleevec and the raw form of imatinib. ${ }^{44}$ The rejection was considered an effective practice to prevent evergreening of pharmaceutical patents and create opportunities for local generic drug

\footnotetext{
${ }^{42}$ According to the national accounts data of the World Bank, India's per capita income (nominal) was USD 1670 (approximately INR 113,710) in 2016. Available at https://data.worldbank.org/ indicator/NY.GNP.PCAP.CD?locations=IN

${ }^{43}$ Harsha Rohatgi, Indian Patent Office Rejects Compulsory Licensing Application, available at http://www.iiprd.com/2013/11/13/indian-patent-office-rejects-compulsory-licensingapplication-bdr-pharmaceuticals-pvt-ltd-vs-bristol-myers-squibb/

${ }^{44}$ Supreme Court of India, Judgment of Civil Appeal Nos. 2706-2716 of 2013, paragraph 128; Gopakumar G Nair, Andreya Fernandes and Karthika Nair, Landmark Pharma Patent Jurisprudence in India, 19 Journal of Intellectual Property Rights (2014), 80 82.
} 
companies. ${ }^{45}$ Novartis case was a benchmark for preventing the evergreening of pharmaceuticals. After 2013, every pharmaceutical patent has to pass the standards set by the Supreme Court in the Novartis case. Meanwhile, in 2014, the Controller framed a new set of guidelines for examining pharmaceutical applications, which incorporates the findings in the Novartis case..$^{46}$

\section{China's Patent Legislation and Patent Protection for Pharmaceuticals}

Compared with other industries, the pharmaceutical industry has its own particularity, as the invention of pharmaceuticals is hugely expensive, and pharmaceuticals are closely related to human rights, such as the right to life and the right to health. The price of a patented drug is substantially higher than that of generic drugs, which affects access to medicine. In the legislative process of China's Patent Law, which was first enacted in 1984 (effective April 1, 1985) and amended three times in 1992, 2000 , and 2008, the issues of whether to grant patent protection for pharmaceutical products, the extent of protection, and exceptions to patent infringement have always been important.

\subsection{From Denying to Recognizing Patent Protection for Pharmaceutical Products}

In 1979, Dr. Árpád Bogsch, the Director General of the WIPO, suggested that China's first patent law should not provide any exceptions to patentability and patent protection should be available for any inventions in all fields of technology. He also suggested that for some technical fields, such as in the pharmaceutical sector, if the patented invention is not worked in China, a compulsory license could be granted to local companies in order to meet public interests. ${ }^{47}$

During the drafting of the Patent Law of 1984, patentable subject matter was a very important issue. There was a heated debate about which inventions should be protected and which should be excluded from the scope of protection under the

\footnotetext{
${ }^{45}$ However, incremental innovation should be distinguished from evergreening. A pharmaceutical company engages in evergreening if it merely modifies the color of the tablet or the inert ingredients of a drug and seeks to patent the modification. However, when a modification increases a drug's bioavailability or absorptivity, it can produce significant improvements in drug delivery and effects, and hence should be treated as an incremental innovation worthy of patent protection; see Jodie Liu, Compulsory Licensing and Anti-Evergreening: Interpreting the TRIPS Flexibilities in Sections 84 and 3(d) of the Indian Patents Act, 56 Harvard International Law Journal, No. 1 (2015), 220.

${ }^{46}$ Office of the Controller General of Patents, Designs and Trademarks, Guidelines for Examination of Patent Applications in the Field of Pharmaceuticals, October 2014.

${ }^{47}$ Zhao Yuanguo, The Formulation and Promulgation of China's Patent Law (in Chinese), Beijing: Patent Literature Publishing House, 2003, 28.
} 
patent law. At the time, there were two very different views regarding the patent protection of pharmaceutical products. The argument that no patent right should be granted to pharmaceutical products was mainly based on the fact that medicines are related to people's physical health and should not be monopolized by a small number of people and that granting patent protection would hinder domestic companies which were lagging far behind their foreign competitors in pharmaceutical technology.

After many discussions, the legislators decided that pharmaceutical products should not be monopolized by patentees for two reasons: first, medicinal supply is closely related to people's health and life. Second, patent would have negative influence on the domestic pharmaceutical industry, because most of the pharmaceutical inventions were created and owned by companies of developed countries. ${ }^{48}$ Under Item 5 of Article 25 of the Patent Law of 1984, no patent right shall be granted for pharmaceutical products and substances obtained by means of a chemical process. In fact, throughout the legislative process, in every version of the draft, including the final one, pharmaceutical products were not listed in the scope of patent protection.

However, on September 4, 1992, the Standing Committee of the National People's Congress adopted the Decision on Amending the Patent Law, which abandoned the stance of denying patent protection for pharmaceutical products of the Patent Law of 1984. This means that, from January 1, 1993, when the amendment took effect, pharmaceutical products and substances obtained by means of a chemical process could be granted patent right, provided that they possess the characteristics of novelty, inventiveness, and industrial usefulness.

One of the major reasons for the amendment of China's Patent Law in 1992 was the execution of the Memorandum of Understanding on the Protection of Intellectual Property Rights between the governments of China and the United States on January 17, 1992. In the memorandum, the Chinese government promised to expand the patentable subject matter in China's Patent Law, i.e., to extend patent protection to all chemical inventions, including pharmaceuticals and agricultural chemicals, whether products or processes. ${ }^{49}$ Since the late 1980 s, in order to obtain full and effective intellectual property protection for American enterprises overseas, the US government held intellectual property negotiations with its trading partners and threatened trade sanctions, in an attempt to force them to accept the American standards for intellectual property protection. ${ }^{50}$ In addition, the Uruguay Round of the GATT adopted the TRIPS Agreement, which stipulates that patent protection should be available for any inventions in all fields of technology. The Amendment of China's Patent Law of 1992 was a response to US trade pressure and the requirements of the TRIPS Agreement.

\footnotetext{
${ }^{48}$ Tang Zongshun, Patent Law (in Chinese), Beijing: Law Press, 1996, 66.

${ }^{49}$ Article 1 of the Sino-US Memorandum of Understanding on the Protection of Intellectual Property Rights, 1992

${ }^{50}$ Wen Xikai, Thoughts on Second Revision of the Chinese Patent Law (in Chinese), 1 China Patents and Trademarks (1999), 16.
} 


\subsection{Compulsory License for Exploitation of Pharmaceutical Patents in Theory but Not in Practice}

The compulsory licensing system was established in China's Patent Law of 1984. According to Articles 51 and 52 of the Patent Law of 1984, the patentee has an obligation to manufacture the patented product or use the patented process in China. If, 3 years after the date of the grant of a patent right, the patentee of an invention or utility model has failed, without any justifiable reason, to manufacture the patented product or use the patented process in China, the Patent Office may, upon the request of a unit possessing the means to exploit the invention or utility model, grant a compulsory license to exploit the patent.

These provisions are very similar to the condition of granting a compulsory license in Indian Patents Act, according to which if the patented invention is not worked in the territory of India within 3 years from the date of sealing a patent, any person may make an application for grant of a compulsory license. Admittedly, the obligation to exploit a patent within a country's territory can increase the value of the patent in the country concerned, as it would promote technical transfer to the country and help the training of relevant technical personnel. For domestic generic companies, this can also mean more opportunities to exploit patents owned by foreign companies.

However, this obligation to exploit a patent in China was cancelled in the Patent Law of 1992, and two other conditions for granting a compulsory license were added in the law. Firstly, where any entity which is qualified to exploit the invention or utility model has made a request for authorization from the patentee to exploit the patent or utility model on reasonable terms and has been unable to obtain such authorization within a reasonable period of time, the Patent Office may, upon the application of such entity, grant a compulsory license to exploit the patent for the invention or utility model. ${ }^{51}$ Secondly, where a national emergency or an extraordinary state of affairs occurs, or where the public interest so requires, the Patent Office may grant a compulsory license to exploit the patent for an invention or utility model $^{52}$

In order to better solve public health problems, the State Intellectual Property Office (SIPO) of China issued the Rules for Compulsory License of Patents concerning Public Health Problems in 2006, which were abolished and replaced by the Rules on the Implementation of Compulsory Patent License issued by the SIPO in 2012. The rules were promulgated for implementing the Doha Declaration on the TRIPS Agreement and Public Health by the WTO Ministerial Conference and Paragraph 6 of the Doha Declaration on the TRIPS Agreement and Public Health by the General Council of WTO.

In the third Amendment, another new circumstance for granting a compulsory license was added in the Patent Law of 2008 (effective October 1, 2009), i.e., for the purpose of public health, the patent administrative department of the State Council

\footnotetext{
${ }^{51}$ Article 51 of the Patent Law, 1992.

${ }^{52}$ Article 52 of the Patent Law, 1992.
} 
may grant a compulsory license for a patented medicine so as to produce and export it to the country or region which conforms to the provisions of the relevant international treaty to which China has acceded. ${ }^{53}$ In accordance with this provision, in case any member of the WTO notifies the TRIPS Council of its desire to import medicines for treating certain epidemic disease(s), or least-developed countries which are nonmembers of the WTO notify the Chinese government through a diplomatic channel of their desire to import from China medicines for treating certain epidemic disease(s), then the relevant department of the State Council may ask the SIPO to grant a compulsory license and allow the licensee to manufacture the relevant kind of medicines and export them to the countries concerned.

As one of the drafters of the patent law has explained, the greatest value of the compulsory licensing system is its deterrent and persuasive effect. ${ }^{54}$ So far, no compulsory license has ever been granted in China. However, every time when the patent law was amended, this issue has always been a contentious topic and received much attention. The reason is that a compulsory license is an important tool to satisfy public interests.

\subsection{From Experimental Use Exception to Bolar Exception}

The Patent Law of 1984 already listed certain acts that were not considered patent infringement, including the use of a patent solely for the purposes of scientific research and experiment. ${ }^{55}$ However, different interpretations on how to define the boundary of the experimental use exception in practice existed. The first dispute arising from a clinical experimental use was handled by the court in 1995. In the GlaxoSmithKline v. Southwest Pharmaceuticals Plant case, the court granted the total damages caused during the clinical experimental use, which implied that the trial per se constituted infringement. ${ }^{56}$ This case also showed that it is difficult for the act of clinical experimental use of patented drugs to be exempted from liability for infringing others' patent rights. Therefore, it is necessary to formulate special provisions to regulate matters relating to the clinical experimental use of patented drugs. ${ }^{57}$

The first so-called Bolar exception case in China, the Sanyo case, was heard in 2006 by the Beijing Second Intermediate People's Court. ${ }^{58}$ In the ruling, the court held that the defendant, Wansheng Pharmaceutical Company, had used Sanyo's patented process to make a drug for the purpose of undertaking a clinical trial and applying for approval of production. This act was aimed at testing the safety and

\footnotetext{
${ }^{53}$ Article 50 of the Patent Law, 2008.

${ }^{54}$ Wen Xikai, The Value of Compulsory Licensing Lies in Deterrence and Dissuasion (in Chinese),

1 China WTO Tribune (2003), 19.

${ }^{55}$ Article 62 of the Patent Law, 1984.

${ }^{56}$ Chongqing First Intermediate People's Court (1995) Zhong Jing Chu No. 406, Civil Judgment.

${ }^{57}$ Wu Yuhe/Liu Zhi, Experimental Use Exemption in Clinical Trial of New Drugs (in Chinese), 2 China Patents and Trademarks (2003), 27.

${ }^{58}$ Beijing Second Intermediate People's Court (2006) Min Chu No. 04134, Civil Judgment.
} 
effectiveness of the drug in order to satisfy the requirement of the relevant state agency for approval of the drug. Given that the defendant did not make the drug directly for the purpose of production and business, the act of clinical trial was not deemed an infringement. The judgment in the Sanyo case was supported by most of the Chinese IP legal practitioners, as the judiciary in China urgently needed to search from the existing provisions of the infringement exemptions contained in the patent law for a basis for not construing a clinical trial as patent infringement. ${ }^{59}$

The regulatory Bolar exception was introduced into the Patent Law of 2008. According to Article 69(5), any person who produces, uses, or imports patented drugs or patented medical apparatus and instruments, for the purpose of providing information required for administrative examination and approval, or any other person who produces or imports patented drugs or patented medical apparatus and instruments exclusively for that person shall not be deemed to have infringed the patent right involved.

\section{$4 \quad$ What Could China Learn from India?}

\subsection{To Fully Utilize the TRIPS Exceptions to Prepare Domestic Pharmaceutical Industry}

The transition period gives some exceptions to the implementation of TRIPS to the developing countries. Noteworthy is that India has fully utilized the transition period to prepare its domestic pharmaceutical industry. When the TRIPS Agreement came into force on January 1, 1995, India was a founding member of the WTO and should have implemented the TRIPS obligations after the 5-year transition period available to a developing country member. However, India made best use of the additional period of 5 years to extend product patent protection to pharmaceutical products. In other words, India only began to fully implement the TRIPS obligation to provide both product and process patent protection for pharmaceuticals starting from January 1, 2005. In contrast, China officially became a WTO member on December 11, 2001, but China had amended its patent law as early as in 1992 and had begun to grant product patent for pharmaceutical products and substances from January 1, 1993, onward, 12 years earlier than India. This period constituted an opportune time slot for preparing the generic drug companies in India to face new competition. Indian domestic companies used the decade not only to strengthen R\&D capabilities but also to dominate the international generic drug market.

\subsection{Legal Professionals Who Understand Global Rules}

After India signed the TRIPS Agreement, Mr. Zheng Xiaoguang, an official of the Chinese Embassy in India, wrote an article to remind Chinese readers that, in the

\footnotetext{
${ }^{59}$ Jiang Hongyi, Compelled Choice Made in Dilemma: Comments on the Issue of Application of Law in the First Case of "Bolar Exception" in China (in Chinese), 4 China Patents and Trademarks (2007), 36.
} 
past, India had always acted independently and declined to make concessions, but after the entry into force of the TRIPS Agreement, India had to extensively amend its patent system to comply with the TRIPS requirements and that while so doing India had paid a price far lower than that of China, especially in the pharmaceutical industry. ${ }^{60}$

This is not only because India was already a member of the GATT and a founding member of the WTO and hence had an inherent advantage. What is more important is that India has several generations of elite lawyers, who use English as their mother tongue and have received a Western education and gained familiarity with the Western legal system. These lawyers hold a global perspective and ability to handle complex global issues and therefore understand how to make full use of the flexibilities of the TRIPS Agreement. China should start to cultivate its lawyers to be internationalized so that they become able to further Chinese interests in the world arena.

\subsection{Measures to Promote Drug Innovation and Develop Generic Drugs}

The Indian government strategically aligns its pharmaceutical policies with its economic ambitions, to suit the domestic interests. ${ }^{61}$ India makes progress step by step, winning valuable opportunities for the local pharmaceutical industry to achieve technical sophistication and garner more market share. However, a realistic strategy and specific measures based on the developmental situation of the domestic pharmaceutical industry were simply lacking in China until 2017.

It is therefore encouraging to see the General Office of the Central Committee of the Communist Party of China and General Office of the State Council issued the Opinions on Deepening the Reform of the Evaluation and Approval Systems and Encouraging Innovation on Drugs and Medical Devices in October 2017, to promote technological innovation in the drug and medical device industries and to enhance their competitiveness so as to meet the health needs of the general public.

In the opinions, the following measures are, inter alia, put forward: (1) to establish a catalog of marketed drugs of China, which shall categorize innovative drugs, modified new drugs, and generic drugs with the same quality and therapeutic effect as the brand-name drugs and contain information such as active ingredients, forms, specifications, holders of marketing licenses, patents obtained, and protection period of trial data; (2) to explore and establish a patent linkage system, which shall link drug evaluation and approval with drug patents, protect the lawful rights and

\footnotetext{
${ }^{60}$ Zheng Xiaoguang, General Agreement on Tariffs and Trade and Indian Patent Law: Analysis of the Current Patent System in India (in Chinese), Patent Law Research (1994), Beijing Patent Literature Publishing House, 1995, 197.

${ }^{61}$ Arpan Banerjee, The Law and Politics of Pharmaceutical Patents in India, in Kung-Chung Liu/ Racherla U. (eds) Innovation and IPRs in China and India. China-EU Law Series, Vol. 4. Springer, 2016, 155.
} 
interests of patent holders, and concomitantly reduce the risks of patent infringements by generic drugs and encourage the development of generic drugs; and (3) to conduct the pilot program of a patent term compensation system, which foresees an appropriate patent term extension for certain new drugs to compensate for the time lost due to delay caused by clinical trial, evaluation, and approval.

\section{Conclusion}

Both China and India are developing countries and need to seek a balance between protecting intellectual property rights and satisfying people's healthcare needs. They also need to promote innovation and encourage the development of domestic industries. As members of the WTO, both China and India have made a series of amendments to their respective legal systems in response to the TRIPS Agreement's standards of intellectual property protection, including the recognition of pharmaceutical product patents, introduction of a compulsory licensing system, and the Bolar exception. In promoting the development of the domestic pharmaceutical industry, India's experience in legislation and judicial practice deserves serious attention from China, such as using TRIPS's flexibility to facilitate access to medicines, implementing compulsory licensing to create more chance for voluntary licensing negotiation, and updating the guidelines for examining pharmaceutical applications to prevent evergreening of pharmaceutical patents. Meanwhile, learning from India, China should start to cultivate its legal professionals to understand global rules, so that they become able to further Chinese interests in the world arena.

Acknowledgments Research funding for this chapter is from the Shenzhen Soft Science Research (Project No. RKX20180413181939223) and Key Research Center of Humanities and Social Sciences of the Ministry of Education of the People's Republic of China (Project No. 14JJD820018).

\section{References}

Banerjee, A. (2016). The law and politics of pharmaceutical patents in India. In K. C. Liu \& U. Racherla (Eds.), Innovation and IPRs in China and India (China-EU Law Series, Vol. 4) (pp. 143-158). Singapore: Springer.

Fernandes, A., \& Nair, K. (2014). Landmark pharma patent jurisprudence in India. Journal of Intellectual Property Rights, 19, 79-88.

JIANG Hongyi. (2007). Compelled choice made in dilemma: Comments on the issue of application of law in the first case of "Bolar exception" in China. China Patents and Trademarks, 4, 35-36. (in Chinese).

Liu, J. (2015). Compulsory licensing and anti-evergreening: Interpreting the TRIPS flexibilities in Sections 84 and 3(d) of the Indian Patents Act. Harvard International Law Journal, 56(1), 207-227.

Mazumdar, M. (2013). Performance of pharmaceutical companies in India. New York: Springer.

Nedumpara, J. J., \& Misra, P. (2012). NATCO v. BAYER: Indian patent authority grants its first ever compulsory license on pharmaceutical products. Global Trade and Customs Journal, 7, 326-330. 
O'Regan, M. (1995). The Protection of Intellectual Property, International Trade and the European Community: The Impact of the TRIPS Agreement of the Uruguay Round of Multilateral Trade Negotiations. Legal Issues of Economic Integration, 22(1), 1-50.

Rohatgi, H. (2013). Indian Patent Office rejects compulsory licensing application. Available from http://www.iiprd.com/2013/11/13/indian-patent-office-rejects-compulsory-licensing-application-bdr-pharmaceuticals-pvt-ltd-vs-bristol-myers-squibb/. Last visited on 2018-02-17.

Sarathy, R. (2016). Strategic evolution and partnering in the India pharmaceutical industry. In S. C. Jain (Ed.), Emerging economies and the transformation of international business: Brazil, Russia, India and China (BRICs) (pp. 229-249). Cheltenham: Edward Elgar Publishing Ltd.

Saxena, R. B. (1988). Trade-related issues of intellectual property rights and the Indian patent act A negotiating strategy. World Competition, 12(2), 81-116.

Shri Justice N. Rajagopala Ayyangar. (1959). Report on the revision of the patent law, Government of India.

TANG Zongshun. (1996). Patent law. Beijing: Law Press. (in Chinese).

WEN Xikai. (1999). Thoughts on second revision of the Chinese Patent Law. China Patents and Trademarks, 1, 16-19. (in Chinese).

WEN Xikai. (2003). The value of compulsory licensing lies in deterrence and dissuasion. China WTO Tribune, 1, 19-20. (in Chinese).

WU Yuhe, \& LIU Zhi. (2003). Experimental use exemption in clinical trial of new drugs. China Patents and Trademarks, 2, 23-24. (in Chinese).

Xiaoguang, Z. (1995). General agreement on tariffs and trade and Indian Patent Law: Analysis of the current patent system in India. Patent law research. Beijing: Patent Literature Publishing House. (1994, in Chinese).

ZHAO Yuanguo. (2003). The formulation and promulgation of China's Patent Law. Beijing: Patent Literature Publishing House. (in Chinese).

Open Access This chapter is licensed under the terms of the Creative Commons Attribution 4.0 International License (http://creativecommons.org/licenses/by/4.0/), which permits use, sharing, adaptation, distribution and reproduction in any medium or format, as long as you give appropriate credit to the original author(s) and the source, provide a link to the Creative Commons license and indicate if changes were made.

The images or other third party material in this chapter are included in the chapter's Creative Commons license, unless indicated otherwise in a credit line to the material. If material is not included in the chapter's Creative Commons license and your intended use is not permitted by statutory regulation or exceeds the permitted use, you will need to obtain permission directly from the copyright holder.

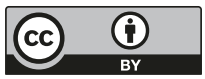

